\title{
Assessing France as a Model of Societal Success
}

\author{
Éloi Laurent \\ Sciences-Po \\ Michèle Lamont \\ Harvard University
}

It is hard to deny that France is back on the global scene: back from a period of relative isolation - which is not unusual-and relative quietness, which is more unusual.* The country's recent period of renewed global activism-playing a high-profile role in international debates on questions as diverse as the future of the financial system to the potential conflict between Israel and Iran-will most certainly reach a peak when France assumes the G20 presidency in November 2010 and G8 presidency in January 2011. Perhaps more importantly, France is back on the European scene, as was most visible in the success of the French Presidency of the European Union in the latter half of 2008 and in France's joint management (with Germany) of the crisis of the Euro area in the spring of 2010. It is probably no coincidence that France returns to global visibility during moments of difficulty, as it continues to claim a role in global leadership.

Much more surprisingly, however, the so-called "French model" has also been mounting something of a comeback. It has received unexpected praise from a number of American and British media sources such as Newsweek ("The Last Model Standing Is France"1) and The Economist ("How France is surviving the economic crisis," "The French model: Vive la difference!"2), and also from free-market minded international organizations such as the Organization for Economic Cooperation and Development (OECD) and the International Monetary Fund (IMF), which have praised the recent resilience of the French economy. 
But what exactly is this apparently successful "French model" and how can it help us understand the forces shaping France's future ${ }^{3}$ There are at least two ways to understand the notion of "model." The first is normative: a national model is an example (usually praised for its economic and social performance) that should be emulated by other countries wishing to be as successful (e.g., the "German model" or "Japanese model" in the late 1980s). ${ }^{4}$ The second is closer to the idea of system: a national model is a consistent set of institutional features persisting in time. Persistence comes from consistency: as long as the model is not destroyed by inner contradictions, it is able to hold competing institutions together. This second definition of "model" is in tension with the first: it is difficult to emulate a national model, to copy-andpaste institutions from one country to another, because a model is a system, one whose institutions are part of a larger configuration. Thus, it makes little sense to attempt to transpose the best aspects of the much-praised "Nordic model" to, say, Spain, Italy or France, in order to solve these countries' worst problems (e.g., with unemployment or income inequality). ${ }^{5}$

As a system, then, what are the central elements of the "French model"? Following in the footsteps of others, we can define it as "statist-republicanist": its economy relies heavily on market regulation and public intervention. However, its democracy revolves around republicanism, defined, after Jean-Jacques Rousseau, as a social contract whereby a universal citizen, abstracted from social and economic conditions (whether residential, religious, or ethnoracial), engages in a direct relationship with the state representing the general will.

Because the global crisis is again "bringing the state back in," ${ }^{6}$ it is not surprising that the present context is favorable to a revival of this "French model": the French economy being heavily regulated, the well-oiled state tightly controls market excesses while massive public and social spending provides a buffer against the worst effects of the economic crisis. When commentators praise the resilience of the "French model," they actually admire the statist facet of the French system that has allowed France to weather the global crisis better than many other countries.

Indeed, because of public regulation, French banks have fared better than their counterparts in a number of advanced industrial societies. Moreover, thanks to a higher domestic demand stimulated by an abundance of so-called "automatic stabilizers," France came out relatively well from the recession of 2009 (with a growth-or better yet de-growth - rate second only to Canada's among the G8 countries). This should come as no surprise: public spending currently amounts to 55 percent of French gross domestic product (GDP), more than any European country, with the exception of Sweden (at 56 percent). Public employment also plays a major role in stabilizing the French economy when the private sector plunges: wages in the public sector amount to almost 15 percent of GDP.

But the role of the state in France goes beyond macroeconomic stabilization. It has been instrumental in building the public goods that now consti- 
tute France's "long-term assets for human development." (Note that the human development index is replacing GDP growth as a measure of relative societal success as the crisis in the financial sector is undermining of economic orthodoxy. $)^{7}$ In our view, these "long-term assets" are fourfold.

First, contrary to most developed countries, especially European countries, France's demography is on an upward trajectory. While on average European countries experienced a decline of overall fertility from the mid-1970s onwards, France was able to increase its birth-rate beginning in the mid-1990s, thanks to pro-family social policies (Table 1). Currently, according to Eurostat, France's fertility rate surpasses that of all EU countries, including Ireland.

Table 1. Total fertility (children per woman), medium variant, 1950-2010

$\begin{array}{lcccc}\text { Period } & \text { France } & \text { Germany } & \begin{array}{c}\text { Western } \\ \text { Europe }\end{array} & \begin{array}{c}\text { Eastern } \\ \text { Europe }\end{array} \\ 1950-1955 & 2.73 & 2.16 & 2.41 & 2.82 \\ 1955-1960 & 2.71 & 2.30 & 2.49 & 2.75 \\ 1960-1965 & 2.85 & 2.49 & 2.67 & 2.45 \\ 1965-1970 & 2.61 & 2.32 & 2.46 & 2.12 \\ 1970-1975 & 2.31 & 1.64 & 1.98 & 2.14 \\ 1975-1980 & 1.86 & 1.52 & 1.67 & 2.08 \\ 1980-1985 & 1.87 & 1.46 & 1.63 & 2.09 \\ 1985-1990 & 1.81 & 1.43 & 1.59 & 2.10 \\ 1990-1995 & 1.71 & 1.31 & 1.50 & 1.62 \\ 1995-2000 & 1.76 & 1.34 & 1.51 & 1.29 \\ 2000-2005 & 1.88 & 1.35 & 1.58 & 1.26 \\ 2005-2010 & 1.89 & 1.32 & 1.59 & 1.35\end{array}$

Source: Population Division of the Department of Economic and Social Affairs of the United Nations Secretariat, World Population Prospects: The 2008 Revision, http://esa.un.org/unpp.

The contrast with Germany is particularly striking. This country's current population is estimated at 82 million - that is, 20 million people more than France. However, the United Nations Population Division predicts that by 2050, Germany's population will have shrunk to 70 million and will surpass France's by only 3 million. ${ }^{8}$

France's second long-term asset for human development is its level of income inequalities, which is relatively low and has generally decreased in recent decades (even if it has increased at the top of the income distribution in recent years). OECD data show that France's level of income inequalities (measured by the Gini index) has declined since the mid-1980s, while it was increasing in the other advanced industrialized societies, with damaging consequences for the social fabric (Table 2). The welfare state has, of course, played a crucial role in reducing income inequalities. 
Table 2. Gini Index for selected advanced industrial societies, Mid-1980s to Mid-2000s

$\begin{array}{lccc} & \text { Mid-1980s } & \text { Mid-2000s } & \text { Difference } \\ \text { Canada } & 0,29 & 0,32 & 0,03 \\ \text { France } & 0,30 & 0,27 & -0,03 \\ \text { Germany } & 0,26 & 0,30 & 0,04 \\ \text { Italy } & 0,31 & 0,35 & 0,04 \\ \text { Japan } & 0,30 & 0,32 & 0,02 \\ \text { United Kingdom } & 0,33 & 0,34 & 0,01 \\ \text { United States } & 0,34 & 0,38 & 0,04 \\ \text { OECD-24 } & 0,26 & 0,31 & 0,05 \\ \text { OECD-22 } & 0,24 & 0,30 & 0,06\end{array}$

Source: OECD, Growing Unequal.

France's third long-term asset for human development is its health care system. It has been ranked by several studies, most notably the 2000 World Health Organization global ranking, as one of the best in the world. (It ranked first in the WHO study, according to an aggregate health performance index.) This, of course, is a controversial matter, and the French health care system is being downsized.

France's fourth asset results from the public investment made in nuclear energy in the late 1970s. The country currently displays the least carbonintensive economic growth in the developed world and fares comparatively well on other indicators of overall environmental quality. For instance, it ranked seven worldwide on the 2010 Environmental Performance Index. ${ }^{9}$

Table 3. Carbon Intensity of Growth* for G-8 Countries

$\begin{array}{lrr} & \mathbf{1 9 9 0} & \mathbf{2 0 0 4} \\ \text { France } & 0,29 & 0,23 \\ \text { Italy } & 0,32 & 0,3 \\ \text { UK } & 0,47 & 0,34 \\ \text { Japan } & 0,37 & 0,36 \\ \text { Germany } & 0,58 & 0,38 \\ \text { US } & 0,68 & 0,56 \\ \text { Australia } & 0,81 & 0,58 \\ \text { Canada } & 0,66 & 0,69\end{array}$

Source: Energy Information Administration database. * ${ }^{*} \mathrm{CO} 2$ emissions per unit of GDP, kilotons of CO2 per million 2000 purchasing power parity US\$)

The combination of these four factors - fertility, fairness, health, and sustainability - are the specific formula behind France's societal success, or its "magic square," to borrow the phrase from growth economist Nicholas Kaldor.

Of course, some of these indicators require further examination. France does less well on measures of inequality other than the Gini Index, and if other timeframes are considered. (Recent research has shown, for instance, 
that income inequalities at the top of the income distribution have substantially increased in the last decade.) More importantly, we need to think beyond these long-term indicators of human development to consider the symbolic dimensions of collective life. These include whether a society: 1) extends recognition to a large number of its residents by, for instance, adopting social policies that favor the integration of migrants and members of underrepresented groups (gays, racial and religious minorities, etc.); 2) promotes full cultural citizenship for its low-income population by, for instance, adopting universal, as opposed to means-tested, mechanisms of redistribution; and 3) has collective myths about national identity and other aspects of social imaginaries that sustain pride, hope, and a positive sense of collective future and possibilities in the population. ${ }^{10}$

In the case of France, these symbolic dimensions of development may be even more important than for other countries, because national myths play a constant implicit or explicit role in public debates. Indeed, there remains a striking gap between the country's political reality and the dominant discourse concerning the polity. This was suggested in the insightful volume co-edited by Peter Hall and others, The Politics that Markets Make. ${ }^{11}$ The authors pointed out that the political discourse concerning French economy, society, and polity has not kept pace with the country's profound structural transformations. In a sense, one could say that the future of France remains symbolically imprisoned by the country's past.

The contradiction between a changing reality and an inert political discourse has not reached a breaking point, due in large part to the central role played by the state in the distribution of public goods. Indeed, for many French citizens the global crisis confirmed the validity of belief in a strong state and a heavily regulated economy. But for others, those who are more attached to the republicanist than to the statist aspects of the French model, this contradiction has become more and more unbearable.

Put simply, as others have pointed out before us, a shadow French model has developed, one that sustains not equality but segregation and discrimination. Societal success should have translated into greater social integration for a larger portion of all those residing on French territory. But the opposite is happening. Five years ago, urban riots shook the country in reaction to the accidental death by electrocution of two teenagers chased by the police in the town of Clichy-sous-Bois. Six months after those riots, we published an op-ed article in the US arguing that "the frustration and resentment expressed by French minorities was largely caused by the contradiction between a fantasized equality and real-life discrimination."12 This is even truer today than it was then.

At the end of 2009, the minister of immigration and national identity (sic), Eric Besson, invited the population to participate in a grand unifying debate on what it means to be French. The debate had to be cut short on account of an abundance of racist statements and vilification of Muslims 
found in many public interventions and online postings. At the same time, a governmental report showed that between 2005 and 2008 the rate of unemployment among residents of French public housing projects had remained twice that of the national average (37 percent for unemployed men between 15 and 24 years old in 2005 compared to 42 percent in 2008 - an all-time high). And study after study shows massive discrimination against minorities in the labor market, the workplace, in dealings with police, and in gaining access to nightclubs and other venues. Yet the "Plan Espoir Banlieue"13 promoted by the new minister of urban integration, Fadela Amara, is widely perceived to be ineffective, as it lacks proper funding and is not supported by strong political commitment. Moreover, social scientists agree that French anti-segregation and anti-discrimination policies are simply not working. It is our belief that no infusion of grand rhetoric about "national identity" can change that. However, the political developments of the summer of 2010 suggest that the worst kind of identity politics will play a major role in the upcoming electoral season: the French public and international press recently witnessed Nicolas Sarkozy, the son of an Hungarian immigrant, casting aside the French "of foreign origin," 14 while his minister of interior, Brice Hortefeux, engaged in a campaign of harassment and deportation of Roma-amidst strong protestation from the Catholic Church and from a wide range of NGOs.

Whatever the rhetoric of isolation and stigmatization, the inability of the French government to improve social integration goes beyond its dealings with visible minorities. Indeed, it fails at integrating youth in general. The babyboomers continue to cherish the powerful mythology of a glorious memory of May 1968 and the image of the triumphant students tearing down cultural barriers by erecting barricades in the Quartier Latin. But this mythology hides the reality that a large part of today's French youth is excluded from the labor market and lives from one short-term contract to the next, with little hope and few prospects. This situation reverberates in French universities, where a generation of young researchers finds itself facing professional dead-ends and has to contend with a delegitimized evaluation system. There is no remedy in sight despite governmental efforts to reform French research and higher education, an attempt greeted by massive opposition on the part of academics, who feel that their expertise is not being respected by state bureaucrats. ${ }^{15}$

The first article in this series, by Louis Chauvel, points precisely to the generational gap that has developed in France and now threatens the democratic balance of the country. The second article by Arthur Goldhammer elegantly tries to see through the mythological smoke to discern deeper trends in the transformation of the idea of French culture. The final paper, on the French carbon tax, also aims to assess the distance between words and deeds concerning low-carbon economic development of France.

As Alexis de Tocqueville famously wrote in Democracy in America, "When the past is no longer capable of shedding light on the future, the mind can only proceed in darkness." ${ }^{16}$ In the contemporary era, the appeal of the French 
model - often contrasted with the American model - is the inclusion of marginal and downtrodden individuals and groups through active state intervention, with the support of republicanism by France's statist tradition. Lest that legacy be lost, it is high time that France revisits its social contract, and remembers its once celebrated inclusive collective imaginary.

Élor LAURENT is senior economist and scientific advisor at OFCE (Sciences-Po Center for Economic Research). A former aide in the French Parliament and for the French prime minister, he has been a visiting scholar at NYU, Columbia University, and the Minda de Gunzburg Center for European Studies at Harvard University. He teaches at Sciences-Po, Stanford University, and La Sorbonne. His most recent books are La Nouvelle Écologie Politique (with Jean-Paul Fitoussi, 2008) and Report on the State of the European Union-EU Governance in Crisis (2009).

Michèle Lamont is the Robert I. Goldman Professor of European Studies and Professor of Sociology and African and African American Studies at Harvard University. She has written widely in the fields of inequality, culture, race, and theory. Her publications include Money, Morals and Manners: The Culture of the French and American Upper Middle Class (1992), The Dignity of Working Men: Morality and the Boundaries of Race, Class, and Immigration (2000), How Professors Think: Inside the World of Academic Judgment (2009), and Successful Societies: How Culture and Inequality Affect Health (co-edited with Peter Hall, 2009).

\section{Notes}

* The articles published here were presented in a series of conferences on "The Future of France" we organized at the Center for European Studies, Harvard University, in the fall of 2009. We express our appreciation to colleagues who served as discussant for the papers assembled here: Mary Brinton (sociology, Harvard University), Herrick Chapman (history, New York University), and Kyoko Sato (sociology and social studies, Harvard University).

1. 10 January 2009.

2. 7 May 2009.

3. For an argument in favor of a broader definition of societal success that includes institutional and symbolic dimensions, see Successful Societies: How Institutions and Culture Affect Health, ed. Peter A. Hall and Michèle Lamont (New York: Cambridge University Press, 2009).

4. Note that the object of international admiration is subject to frequent change and sometimes brutal reconsideration, as with Japan. 
5. On this last point, see for instance Jean-Paul Fitoussi and Éloi Laurent, "Hawk and Handsaws: What Can France Learn from the 'Nordic Model'?" Center for European Studies Working Papers 168 (Harvard University, 2008).

6. We borrow this variation on the famous phrase from Vivien A. Schmidt, "Putting Politics Back into the Political Economy by Bringing the State Back in Yet Again," World Politics 61, 3 (2009): 516-48.

7. Thus it is not surprising that the president of the French Republic, Nicolas Sarkozy, convened an international commission in February 2008 to review, and if possible improve, the measurement of social progress and economic performance, with special attention to GDP. This commission comprised an international group of twenty scholars, nineteen economists and one sociologist, including five Nobel Prize winners, with Joseph Stiglitz as chairman, Amartya Sen as a special advisor, and JeanPaul Fitoussi as coordinator. The commission released its Report in September 2009. http://www.stiglitz-sen-fitoussi.fr/en/index.htm

8. Population Division of the Department of Economic and Social Affairs of the United Nations Secretariat, World Population Prospects: The 2008 Revision, http://esa.un.org/ unpp.

9. The 2010 Environmental Performance Index (EPI) ranks 163 countries on twentyfive performance indicators tracked across ten policy categories covering both environmental public health and ecosystem vitality.

10. On these aspects, see Hall and Lamont, eds., Successful Societies.

11. Pepper D. Culpepper, Peter A. Hall, and Bruno Palier, eds., Changing France: The Politics that Markets Make (New York: Palgrave Macmillan, 2006).

12. "France Shows Its True Colors," The Boston Globe, 3 June 2006 and "Identity: France Shows Its True Colors," The International Herald Tribune, 6 June 2006.

13. For a presentation of challenges and initial ambitions, see "Plan espoir banlieue: une nouvelle dynamique pour la France," http://www.gouvernement.fr/ gouvernement/espoir-banlieues-pour-une-france-fiere-de-sa-diversite.

14. Nicolas Sarkozy, "Prise de fonction du nouveau préfet," 30 July 2010, Grenoble.

15. Bruno Cousin and Michèle Lamont, "The French Disconnection," Times Higher Education, 3-9 December 2009; Bruno Cousin and Michèle Lamont, "Les conditions de l'évaluation universitaire: Quelques réflexions à partir du cas américain," Revue Mouvements 60 (2009): 113-17.

16. Alexis de Tocqueville, Democracy in America, trans. Arthur Goldhammer (New York: The Library of America, 2004), 831. 